Article

\title{
Quarter-Century Offshore Winds from SSM/I and WRF in the North Sea and South China Sea
}

\author{
Charlotte Bay Hasager ${ }^{1, *}$, Poul Astrup ${ }^{1}$, Rong Zhu ${ }^{2}$, Rui Chang ${ }^{2}$, Merete Badger ${ }^{1}$ and \\ Andrea N. Hahmann ${ }^{1}$ \\ 1 DTU Wind Energy, Roskilde 4000, Denmark; poas@dtu.dk (P.A.); mebc@dtu.dk (M.B.); \\ ahah@dtu.dk (A.N.H.) \\ 2 China Meteorological Administration, Beijing 10081, China; rongzhu@cma.gov.cn (R.Z.); \\ changrui@cma.gov.cn (R.C.) \\ * Correspondence: cbha@dtu.dk; Tel.: +45-4677-5014
}

Academic Editors: Xiaofeng Li and Prasad S. Thenkabail

Received: 4 April 2016; Accepted: 12 September 2016; Published: 20 September 2016

\begin{abstract}
We study the wind climate and its long-term variability in the North Sea and South China Sea, areas relevant for offshore wind energy development, using satellite-based wind data, because very few reliable long-term in-situ sea surface wind observations are available. The Special Sensor Microwave Imager (SSM/I) ocean winds extrapolated from $10 \mathrm{~m}$ to $100 \mathrm{~m}$ using the Charnock relationship and the logarithmic profile method are compared to Weather Research and Forecasting (WRF) model results in both seas and to in-situ observations in the North Sea. The mean wind speed from SSM/I and WRF differ only by $0.1 \mathrm{~m} / \mathrm{s}$ at Fino1 in the North Sea, while west of Hainan in the South China Sea the difference is $1.0 \mathrm{~m} / \mathrm{s}$. Linear regression between SSM/I and WRF winds at $100 \mathrm{~m}$ show correlation coefficients squared of 0.75 and 0.67 , standard deviation of $1.67 \mathrm{~m} / \mathrm{s}$ and $1.41 \mathrm{~m} / \mathrm{s}$, and mean difference of $-0.12 \mathrm{~m} / \mathrm{s}$ and $0.83 \mathrm{~m} / \mathrm{s}$ for Fino1 and Hainan, respectively. The WRF-derived winds overestimate the values in the South China Sea. The inter-annual wind speed variability is estimated as $4.6 \%$ and $4.4 \%$ based on SSM/I at Fino1 and Hainan, respectively. We find significant changes in the seasonal wind pattern at Fino1 with springtime winds arriving one month earlier from 1988 to 2013 and higher winds in June; no yearly trend in wind speed is observed in the two seas.
\end{abstract}

Keywords: wind energy; offshore wind resource; wind speed trends; SSM/I; WRF; North Sea; South China Sea

\section{Introduction}

Offshore wind energy is one of the renewable energy sources to be exploited in Europe, Asia and North America to reduce anthropogenic emission of greenhouse gases from the energy mix. At present, the offshore wind climatology and derived wind power statistical information such as wind resources, wind speed decadal trends, changes in seasonal winds and inter-annual wind speed variability have insufficient detail for siting and planning of offshore wind farms. The main reason is that observations at offshore meteorological masts are very limited in space and time. Data from global reanalysis during recent 25 years are unfortunately not consistent in time due to changes in available input and difficulty in homogenization, thus artificial trends may occur [1].

Wind climate statistics must be known locally for any potential wind farm project. Wind farms are planned with around 30-year economical lifetimes. Often only one or few years of meteorological observations are available and resource estimation has high uncertainty as surface winds change considerably between years [2]. An implicit assumption is that the mean wind resource assessed from stationary climate during the analysis period will be similar into the future.

The collected ship data in the International Comprehensive Ocean-Atmosphere Data Set (ICOADS) [3,4] show wind climate trends at decadal scale over the global oceans. Wind speed 
from four first-generation re-analyses were compared to recently updated ship wind data at $10 \mathrm{~m}$ [5], as well as to wind speeds from satellite passive microwave [6] and altimeter [7-9]. These studies report positive trends in global ocean mean wind speed. This is in contrast to the results of wind speed trend analysis over land based on atmospheric modeling for the USA [10] and Europe [11] and from network of meteorological stations, e.g., in Scotland [12] and China [13]. There is much variability in the decadal wind speed trends for different periods and observational data sets at regional scale for land and sea and include both negative and positive trends. Offshore wind power estimates at global scale based on satellite scatterometer winds show large spatial variations $[14,15]$.

The present study focuses on quarter-century offshore wind speed trends and addresses, with similar methodology and observations, two regional seas both highly relevant for offshore wind farming but with contrasting wind climates. In the North Sea many wind farms are in operation in the UK, Denmark, Germany, the Netherlands and Belgium, while in the South China Sea wind farms are planned with $1.2 \mathrm{GW}$ for 2020, and beyond this time, up to $3.95 \mathrm{GW}$ according to the China National Energy Administration including the Hainan Floating wind farm demo project (20 MW), Guangdong Dongfang wind farm (350 MW), Huaneng Hainan Wenchang \#1 offshore wind farm (200 MW) and Guangdong-Xuwen offshore wind power demonstration project (48 MW) (under construction) [16].

Regional studies using scatterometer winds demonstrate good wind energy potential in the North Sea $[17,18]$ and South China Sea $[19,20]$. Wind resource analysis at higher spatial resolution from satellite synthetic aperture radar (SAR) confirms the good wind energy potential for the North Sea [21,22] and South China Sea [23] and reveals spatial variability at kilometer scale often with sharp gradients near coastlines, where most offshore wind farm projects are located.

The most common problem for assessment of offshore long-term wind climate is the lack of meteorological mast observations. Therefore, satellite-based sea surface wind data are used in this study. Data from SAR satellites cover near-coastal regions, but their temporal coverage is too low for trend analysis. In contrast, passive microwave satellite wind products cover only open oceans but are frequent in time and have a quarter-decadal data record. For long-term wind trend analysis, it is assumed that regional effects rather than local effects govern potential long-term changes. Therefore, we examine what useful information we may extract from the Special Sensor Microwave Imager (SSM/I) ver. 7 that has accuracy sufficient for trend analysis for decadal changes at 1\% [24]. We compare the SSM/I wind speed data to available in-situ data and mesoscale model results. We investigate the strength and weaknesses of the different data sets. Meteorological observations are only available in the North Sea while SSM/I and output from mesoscale simulations using the Weather, Research and Forecasting (WRF) model are available for both seas.

The first objective of this paper is to examine wind power statistics at hub-height of offshore wind turbines at $100 \mathrm{~m}$ from SSM/I and WRF for both seas.

The second objective is to assess the amplitude of temporal wind speed variations and how these vary across the North Sea and the South China Sea by performing long-term trend analysis at monthly and yearly time scale using Student's $t$-test for significance based on SSM/I.

The analysis is based on 26 years of SSM/I ocean wind speeds extrapolated from $10 \mathrm{~m}$ to $100 \mathrm{~m}$ using a logarithmic wind profile and an assumption of neutral stability and wind-induced roughness of the sea [25]. The information on atmospheric stability and boundary layer height is not used within the long-term trend analysis, even though both parameters are known to influence marine boundary-layer wind profiles [26,27]. We choose this because we otherwise would have to use information on these parameters from a model. We do not know if stability and boundary layer heights are constant during the years and if they are modeled correctly. Thus, using this information could contaminate the analysis based on raw data. We investigate the quality of the SSM/I observations compared to in-situ observations on a weekly basis at $100 \mathrm{~m}$ level. The in-situ observations are available at around $100 \mathrm{~m}$ in the North Sea [28,29]; thus, this comparison study is complementary to classical satellite wind comparison based on $10 \mathrm{~m}$ buoy observations [24]. In addition, we add an analysis on stability 
based on WRF to estimate the bias due to stability effects on the mean wind speed at the two sites. The two novelties in this study are: (1) a consistent method applied in both a temperate area and in the tropics based on SSM/I for wind energy applications; and (2) the estimation of stability correction.

\section{Data and Methods}

\subsection{SSM/I Wind Speed Observations at Study Sites}

Our analysis is based on ocean winds observed by the SSM/I series F08, F10, F11, F13, F14, and F15 and the Special Sensor Microwave Imager Sounder (SSM/IS) series F16 and F17 from the Defense Meteorological Satellite Program in the USA. SSM/I ver. 7 data from Remote Sensing Systems (www.remss.com) are used.

SSM/I wind speed data has been inter-calibrated between sensors and in time across the globe in order to reduce the error in the wind speed retrieval process. Thus, we assume the wind speed observed from each of the sensors to be stable in time. According to [24] the accuracy of the SSM/I series is now of a quality feasible for wind climate studies, i.e., changes in wind speed within $1 \%$ per decade can be assessed. The retrieved wind is the equivalent neutral wind speed at $10 \mathrm{~m}$ above mean sea level (AMSL). The SSM/I satellites are in polar orbits and each satellite passes most points on Earth twice per day. From August 1987 to April 1991, only one SSM/I satellite was in operation and a local point of interest was typically passed only twice per day. Later, two to five satellites were in operation and thus the number of daily satellite passes has varied between two and ten. Not all passes, however, produce a valid measurement since the data are flagged out during rain events.

The North Sea and South China Sea with the selected study sites are shown in Figure 1. The SSM/I data are available at $0.25^{\circ}$ by $0.25^{\circ}$ grid. The SSM/I wind speed values from the four nearest grid cells at each site have been averaged and used to represent the site value. The geographical coordinate of the Fino1 mast is $54.0143^{\circ} \mathrm{N}, 6.5877^{\circ} \mathrm{E}$ while the SSM / I center coordinate is $54.25^{\circ} \mathrm{N}, 6.50^{\circ} \mathrm{E}$. The averaging area for Fino1 is offset to the north compared to the mast position because the SSM/I satellites close to the coast register no values. The location in the South China Sea west of Hainan Dao is $19.25^{\circ} \mathrm{N}$, $107.50^{\circ} \mathrm{E}$ and is here called Hainan.


Figure 1. Maps of the study sites and the SSM/I average areas indicated with red boxes the sites: Fino1 in the North Sea (left); and Hainan in the South China Sea (right).

To have full years of data, all available SSM/I observations from 1988 to 2013 are selected. The data from eight satellites operating in different, but partly overlapping periods, have been extracted to form a single series of measurements for each of the sites. There are in total 45.146 samples at Fino1 and 27.188 at Hainan. All samples were used in the analysis and assumed to be independent observations. The average number of samples over the 26-year study period is 4.8 measurements per day at the 
Fino1 site and 2.9 at Hainan. This difference reflects fewer passes locally near the Equator than at higher latitudes due to the scan pattern of polar orbiting Earth satellites. Figure 2 graphs the number of validated SSM/I observations in the North Sea and the South China Sea per year from 1988 to 2013.

The equatorial crossing times for the eight SSM/I satellites are published at Remote Sensing Systems (www.remss.com/support/crossing-times). All satellites drifted in time during the years. Figure 3 shows the number of valid measurements as function of time of day during 26 years. There is much data from 5:00 a.m. to 11:00 a.m. and from 5:00 p.m. to 9:30 p.m., few data from 4:00 a.m. to 5:00 a.m. and from 3:30 p.m. to 5:00 p.m., and no data from 10:00 p.m. to 4:00 a.m. and from 11:30 a.m. to 3:30 p.m. local standard time (LST). If there is a pronounced diurnal cycle in wind speed, this is not fully resolved by SSM/I.
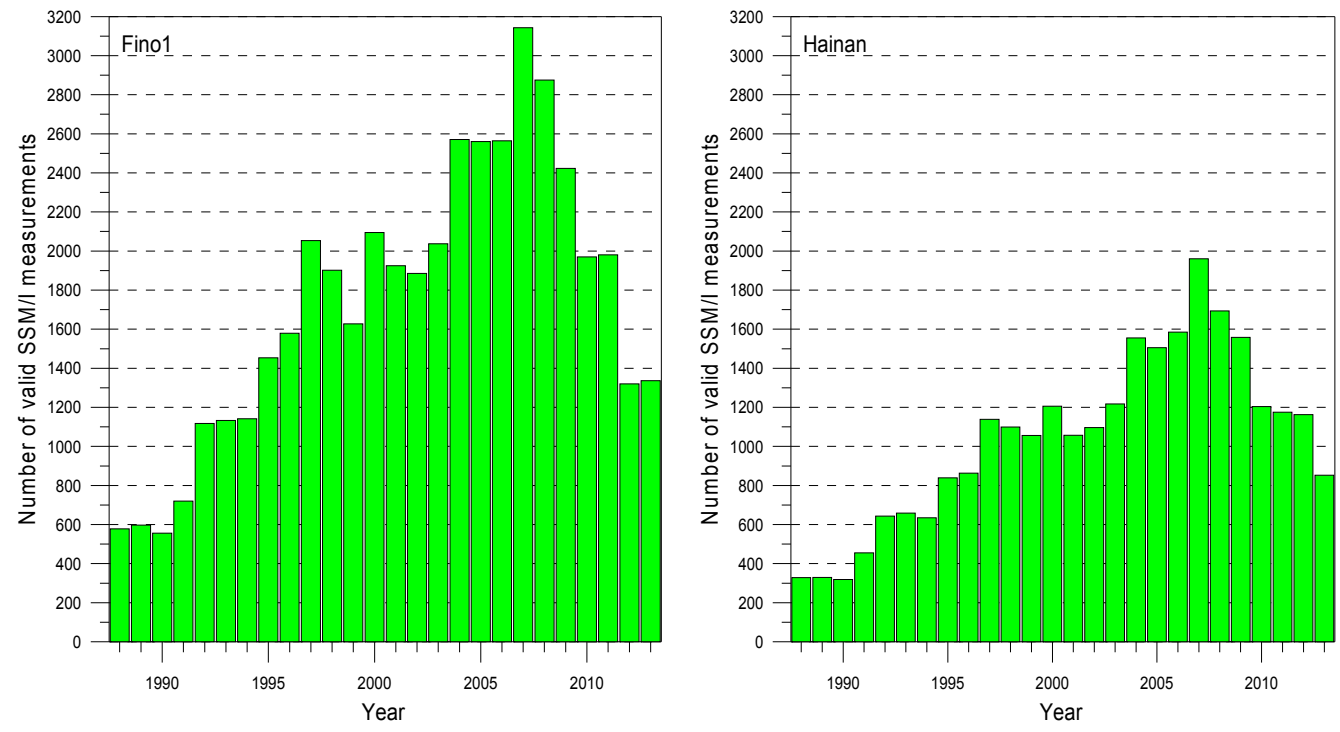

Figure 2. Number of validated SSM/I observations per year at: Fino1 (left); and Hainan (right).
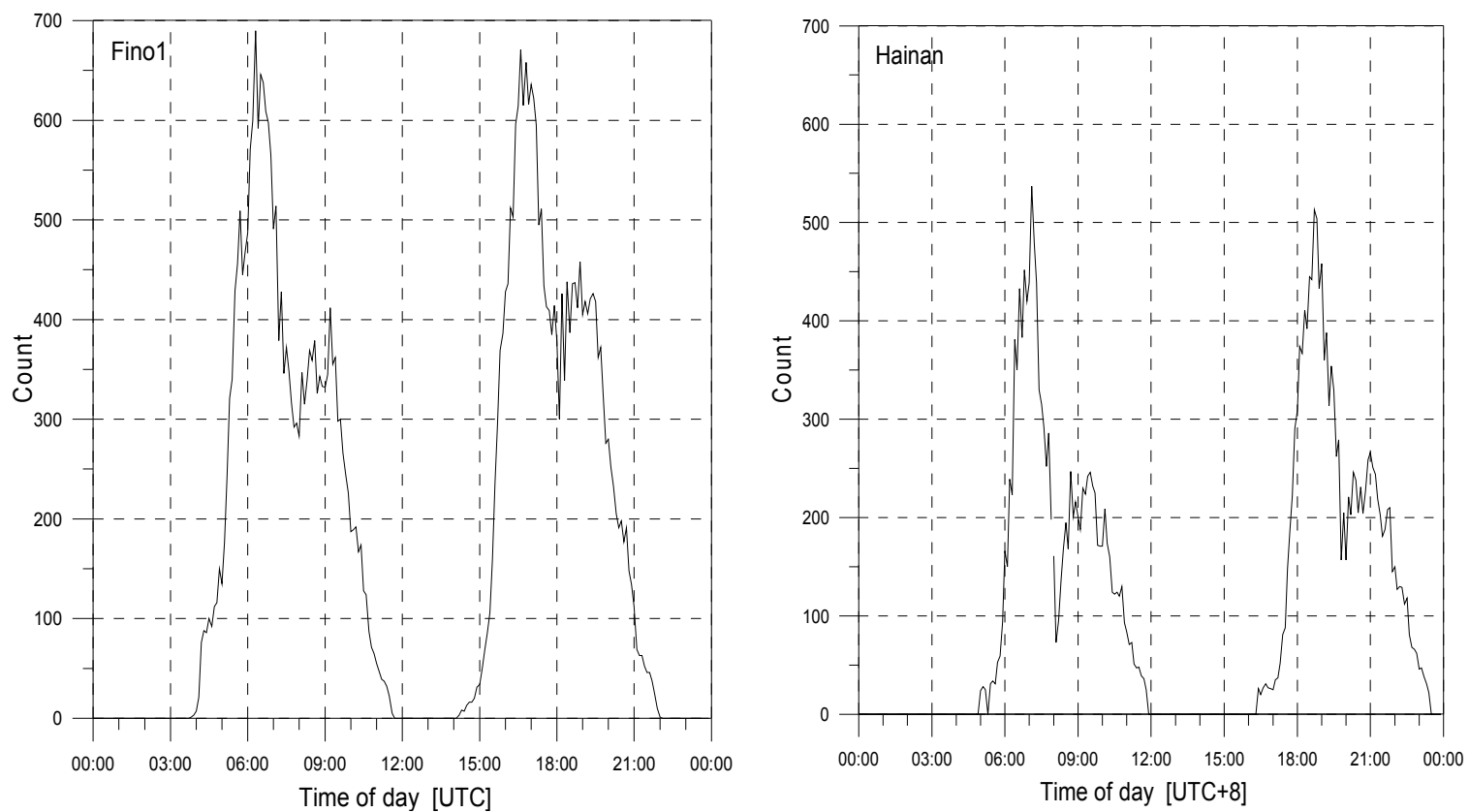

Figure 3. Total number of valid measurements from SSM/I at each registered time point of day using 6-min bins in the period from 1988 to 2013 for: Fino1 (left); and Hainan (right). 


\subsection{Meteorological Mast Data}

The Fino1 meteorological mast observations of wind speed at $100 \mathrm{~m}$ for 2004-2013 in 10-min temporal resolution are used is this study. Fino1 is operated by Bundesamt für Seeschifffart und Hydrographie. The Fino1 wind speed data has been used in several studies [26,28,29]. In September 2009, the Alpha Ventus wind farm east of Fino1 came into operation and since then turbine wake influence (reduce) the mast wind speed observations for easterly winds. We include easterly winds in the analysis, as the effect is minor according to [29]. The wind data from Fino1 show typical mid-latitude wind conditions with winds from all directions and dominated by southwesterly winds [26,29].

\subsection{WRF Model Data}

We use the WRF model [30] in mesoscale reanalysis mode, as introduced in [29], to obtain wind climatology for the two areas of interest. Previous simulations over the North and Baltic Sea using this method found biases in annual mean wind speed between model and observations at heights around $100 \mathrm{~m}$ smaller than $3.2 \%$ at all available offshore sites, except for those that are affected by the wake of a wind farm or the coastline [29]. In contrast, the winds derived from two reanalysis products show larger bias than WRF; it was concluded that the WRF model downscaling is an added value in connection with wind energy application [29]. The WRF method has also been validated against satellite-derived winds in the North and Baltic Sea [18]. In the study on comparison of reanalysis products, blended satellite products and WRF model simulations to buoy winds observed in the Atlantic Sea near Portugal and Spain, the analysis show higher correlation to WRF than to the reanalysis products and blended satellite products, e.g., the French Research Institute for the Exploitation of the Sea Blended Wind Fields (IFREMER-BWF) and the Cross-Calibrated Multi-Platform Ocean Surface wind Vectors (CCMP) [31]. Therefore we use WRF model results in the current study.

For the mesoscale reanalysis used for the North Sea, the WRF model (ARW-WRF version 3.5.1) was run by DTU Wind Energy using ERA-Interim reanalysis [32] with $0.75^{\circ}$ by $0.75^{\circ}$ horizontal grid spacing and sea surface temperatures (SST) with horizontal resolution $0.25^{\circ}$ by $0.25^{\circ}$ (NOAA Daily OISST) [33]. The model was integrated on a grid with horizontal spacing of $18 \mathrm{~km}$ by $18 \mathrm{~km}$ (outer domain, D1) and $6 \mathrm{~km}$ by $6 \mathrm{~km}$ (nested domain, D2). A map of the model setup location, which was rotated to better cover the region of interest, is displayed in Figure 4. Table 1 presents other key information. In the vertical, the model was configured with 41 levels with model top at $50 \mathrm{hPa}$. The lowest 12 of these levels are within $1000 \mathrm{~m}$ from the surface and the first level is located at approximately $14 \mathrm{~m}$ above ground level (AGL). The simulation covers the period 1982-2013, but only output from 1988 to 2013 is used here. The simulations use the YSU PBL scheme [34].

The WRF model used for the South China Sea (ARW-WRF version 3.4) was run by the China Meteorological Administration (CMA). The initial boundary conditions and fields for grid nudging are from NCEP CFSR data at $0.5^{\circ}$ by $0.5^{\circ}$ grid [35]. The model was integrated on a grid with horizontal spacing of $15 \mathrm{~km}$ by $15 \mathrm{~km}$ (outer domain, D1) and $5 \mathrm{~km}$ by $5 \mathrm{~km}$ (nested domain, D2). There are 36 vertical layers with model top at $50 \mathrm{hPa}$. Eight of the layers are placed within $300 \mathrm{~m}$ of the surface. The simulation covers the period from 1989 to 2013. The nested domain is simulated for fewer years [23]. Output only from the outer domain is used in this study. The simulations use the Mellor-Yamada-Janjic (MYJ) scheme [36]. See Figure 4 and Table 1 for further information.

The choice of global reanalysis (ERA Interim versus CFSR) and PBL schemes-MYJ and YSU, which are the two most used schemes in WRF-show only weak sensitivity for winds over the sea according to [29]. In the South China Sea similar sensitivity analysis has not been performed due to lack of offshore meteorological mast data for verification. The results in [29] may not be valid over sea in other geographical regions and climates with, e.g., fewer data assimilated to the reanalysis and dominated by atmospheric processes different from the Northern European seas large-scale weather phenomena. It is beyond our scope to elaborate further on WRF modeling. 

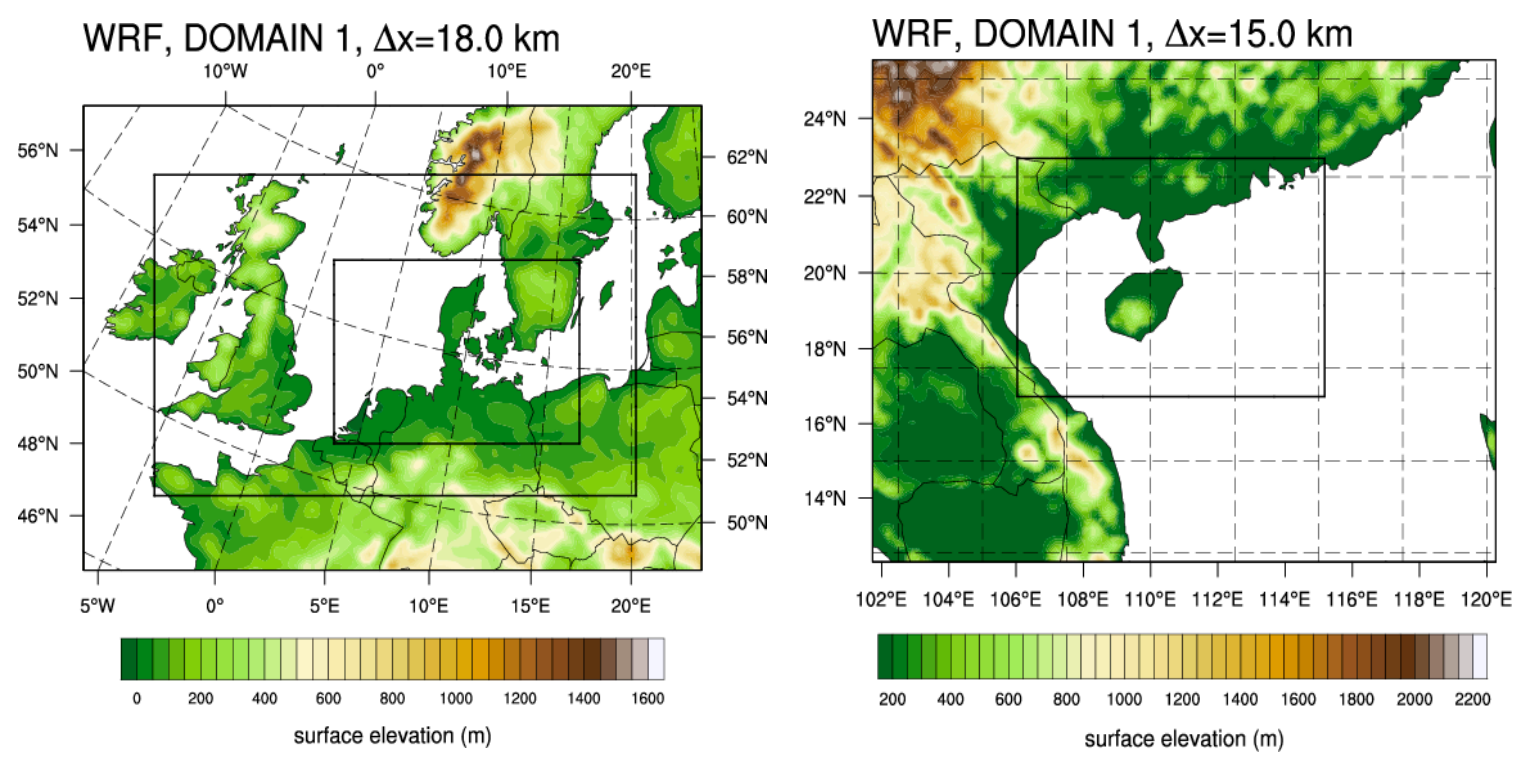

Figure 4. WRF model nested domains for: the North Sea (left); and South China Sea (right).

Table 1. Details of the WRF simulations for the North Sea and South China Sea used in the present study.

\begin{tabular}{ccc}
\hline & North Sea & South China Sea \\
\hline Horizontal grid spacing $(\mathrm{km})$ & 6 & 15 \\
Years & $1988-2013$ & $1989-2013$ \\
Output time step (hours) & 1 & 1 \\
PBL scheme & YSU & MYJ \\
Forcing and boundary data & ERA-Interim + OISST & NCEP/CFSR + OISST \\
\hline
\end{tabular}

\subsection{Extrapolating Wind Speed from $10 \mathrm{~m}$ to Hub-Height}

The SSM/I wind speed observations are valid at $10 \mathrm{~m}$ AMSL. We extrapolate these instantaneous winds to the hub-height of typical offshore wind turbines at around $100 \mathrm{~m}$. The SSM/I wind speed data are extrapolated using the Charnock sea roughness equation for open seas [25] and a logarithmic wind profile: $u^{*} u_{*}$

$$
\begin{aligned}
z_{0} & =0.011 \cdot u *{ }^{2} / g \\
u_{z} & =u * / \kappa \cdot \ln \left(z / z_{0}\right)
\end{aligned}
$$

The surface roughness length $\left(z_{0}\right)$ is a function of the friction velocity $\left(u_{*}\right)$ and gravitational acceleration $(g)$ and is used in the logarithmic wind profile where $u_{z}$ is the wind speed a height $z$ and $\kappa$ is the von Kármán constant. The logarithmic profile is valid when conditions are horizontally homogeneous, and the neutrally stratified constant flux layer is controlled by surface friction. The Charnock formulation is derived for fully developed, wind-generated waves over deep sea. With the satellite given wind speed at $10 \mathrm{~m}, z_{0}$ and $u *$ can be found from the two above equations by iteration and the latter can then be applied for $100 \mathrm{~m}$. In Appendix A, further details on the roughness are given.

For very low wind speeds the above procedure can lead to a value of $u *$ that is below the friction at a smooth wall. As this is not physically realistic, a two layer wind profile [37] is used in that case, a sub-laminar layer close to the wall and a logarithmic layer that matches the measured values at $10 \mathrm{~m}$ and the sub-laminar layer at $z+=11.65$, where $z+=u * \cdot z / v$. If the wind speed is sufficiently small, the laminar sub layer can stretch all way out passed $z=10 \mathrm{~m} . z+$ is the height and $v$ is the kinematic viscosity. 
The vertical extrapolation of wind speeds from SSM/I is performed without any correction for atmospheric stability effects because no observations of heat fluxes and air temperatures are available at the two sites investigated. Instantaneous outputs of these parameters from WRF are too uncertain to be used for estimation of a stability correction parameter [38]. Over the long-term (i.e., over periods of at least one year), however, a stability correction parameter calculated from the same WRF outputs has been found to match mast observations very well [38]. The correction is based on adaptation of the Monin-Obukhov similarity theory and it can be utilized to extrapolate the annual mean wind speed retrieved from satellite observations from $10 \mathrm{~m}$ to higher levels [27].

In order to show the long-term average effect of atmospheric stability on the wind profiles at Fino1 and Hainan, we calculate the long-term stability correction for each of the two sites. For this we use hourly results from WRF during years 2002 to 2012 at $6 \mathrm{~km}$ resolution at Fino1 and hourly results from WRF during years 2009 to 2011 at $5 \mathrm{~km}$ resolution at Hainan.

\subsection{Wind Energy Statistics}

Wind resource assessment is the procedure by which wind power developers estimate the future energy production of a wind farm. The wind resource is key information for wind farm planning [39]. The wind resource usually is calculated from the wind speed and wind direction observations by dividing the wind data into twelve $30^{\circ}$ wind direction sectors. For each sector the Weibull scale $(A)$ and shape $(k)$ parameters are determined from fitting a distribution to the data [40]. Often the data are from a meteorological mast and comprise hourly values for one year. In the current study only the wind speed enters the calculation based on SSM/I and WRF to make these two results comparable. The method used for fitting the Weibull parameters to the distribution of data is from the Wind Atlas Analysis and Application Program (WAsP) [41].

The wind power density, $E$, is calculated from Weibull $A$ and $k$ using the gamma function $(\Gamma)$ and a standard air density $\left(\rho=1.245 \mathrm{~g} / \mathrm{m}^{3}\right)$ :

$$
E=0.5 \rho A^{2} \Gamma(1+3 / k)
$$

In wind energy, a common measure for inter-annual wind variability is the standard deviation of annual mean wind speed over several years in percent of the long-term mean wind speed.

\section{Results}

\subsection{Linear Correlation between Wind Speeds from SSM/I, in-Situ and WRF}

The SSM/I wind speeds extrapolated to $100 \mathrm{~m}$ assuming neutral stability and WRF model winds at $100 \mathrm{~m}$ have been compared to in-situ measurements observed at Fino1 in the North Sea. Weekly averages of wind speeds are selected for comparison in order to balance the number of observations of the data sets and to have sufficient number of observations for linear regression analysis. The results are presented in Figure 5 and in Table 2. Table 2 also presents linear correlation results for SSM/I vs. WRF at $10 \mathrm{~m}$ and at $100 \mathrm{~m}$ for Fino1 and Hainan. The corresponding graphics are given in Figure 5. Please note all available data from Fino1, from WRF and from SSM/I are used in the weekly averages. 



Figure 5. (Top) SSM/I (left) and WRF (right) weekly-averaged wind speed versus in-situ wind speed for Fino1 at 100 m including linear regression results; (middle) SSM/I versus WRF weekly-averaged wind speed at $10 \mathrm{~m}$ for Fino1 (left) and Hainan (right); and (bottom) SSM/I versus WRF weekly-averaged wind speed at $100 \mathrm{~m}$ for Fino1 (left) and Hainan (right). 
Table 2. Linear correlation results between weekly-averaged SSM/I, in-situ and WRF wind speeds in the North Sea and South China Sea. $N$ is the number of samples.

\begin{tabular}{|c|c|c|c|c|c|c|c|c|}
\hline & \multicolumn{4}{|c|}{ Fino1 } & \multicolumn{4}{|c|}{ Hainan } \\
\hline & $\begin{array}{c}R^{2} \\
(\mathrm{~m} / \mathrm{s})\end{array}$ & $\begin{array}{l}\text { Std. Dev. } \\
(\mathrm{m} / \mathrm{s})\end{array}$ & $\begin{array}{l}\text { Mean Diff. } \\
(\mathrm{m} / \mathrm{s})\end{array}$ & $N$ & $\begin{array}{c}R^{2} \\
(\mathrm{~m} / \mathrm{s})\end{array}$ & $\begin{array}{l}\text { Std. Dev. } \\
(\mathrm{m} / \mathrm{s})\end{array}$ & $\begin{array}{l}\text { Mean Diff. } \\
(\mathrm{m} / \mathrm{s})\end{array}$ & $N$ \\
\hline SSM/I vs. in situ at $100 \mathrm{~m}$ & 0.72 & 1.75 & 0.12 & 518 & - & - & - & - \\
\hline WRF vs. in situ at $100 \mathrm{~m}$ & 0.91 & 0.79 & -0.32 & 516 & - & - & - & - \\
\hline SSM/I vs. WRF at $100 \mathrm{~m}$ & 0.75 & 1.67 & -0.12 & 1347 & 0.67 & 1.41 & 0.83 & 1208 \\
\hline SSM/I vs. WRF at $10 \mathrm{~m}$ & 0.88 & 0.98 & -0.12 & 1347 & 0.71 & 1.01 & 0.83 & 1208 \\
\hline
\end{tabular}

SSM/I-derived winds vs. in-situ at $100 \mathrm{~m}$ have lower correlation than those derived from WRF vs. in-situ at $100 \mathrm{~m}$. This is likely a consequence of errors introduced by the vertical extrapolation. The relationship between the SSM/I data observed at $10 \mathrm{~m}$ and extrapolated to $100 \mathrm{~m}$ values using the Charnock's equation is a smooth function of wind speed while WRF uses a sophisticated atmospheric model whose PBL scheme takes heat and humidity fluxes as well as time derivatives of winds into account when determining the winds at all heights. SSM/I vs. WRF winds show higher correlation at $10 \mathrm{~m}$ than $100 \mathrm{~m}$ at both sites. The mean difference between SSM/I- and WRF-derived winds is higher in the South China Sea than in the North Sea. Co-located hourly data at $10 \mathrm{~m}$ based on SSM/I vs. WRF for Fino1 and Hainan show linear correlation results of, respectively, $R^{2} 0.88$ and 0.82, std. dev. 1.71 and 1.84, mean difference 0.0 and 0.0 based on $N 38.547$ and 23.130 .

The influence of atmospheric stability on the vertical wind profile we investigate for a shorter period using the method presented in [27]. The long-term average wind profiles calculated with and without stability correction for Fino1 and Hainan are shown in Figure 6. It shows, in the long term, near-neutral conditions at Fino1 and unstable conditions at Hainan with around $0.5 \mathrm{~m} / \mathrm{s}$ lower winds at $100 \mathrm{~m}$ including stability.
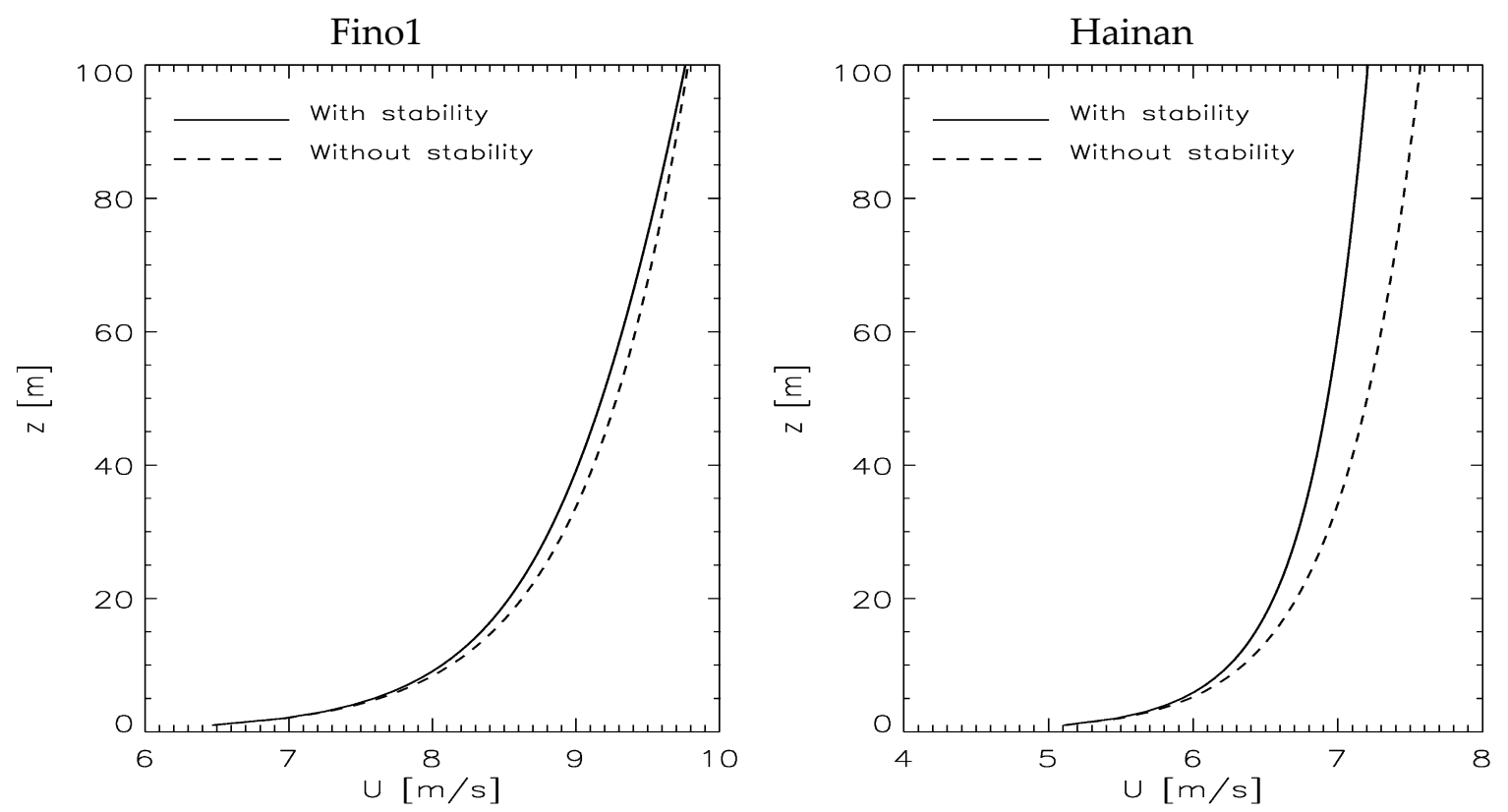

Figure 6. Long-term averaged wind profiles with and without stability correction at: Fino1 (left); and Hainan (right).

\subsection{Comparison of Wind Resource Statistics from SSM/I and WRF}

The monthly averages of wind speed based on SSM/I and WRF at $100 \mathrm{~m}$ for Fino1 (1988-2013) and Hainan (1988-2013; but 1989-2013 in WRF) are shown in Figure 7. At Fino1, the WRF mean wind 
estimates are higher than from SSM/I from February through June, and lower from August through January. At Hainan, the WRF estimates are higher than SSM/I for all months.

The wind speed distribution and fitted Weibull curves from SSM/I and WRF for Fino1 and Hainan are shown in Figure 8. For Fino1 meteorological data at $100 \mathrm{~m}$ for much fewer years are included. The estimates from SSM/I, WRF and meteorological data compare well at Fino1, while for Hainan the wind speed distribution from WRF is shifted towards higher values than from SSM/I. The mean wind speed, Weibull scale and shape parameters, energy density and inter-annual wind speed variability for Fino1 and Hainan are listed in Table 3. The inter-annual wind speed variability at Fino1 is $4.6 \%$ based on SSM/I and $0.6 \%$ lower based on WRF. In contrast, at Hainan based on SSM/I, the value is $4.4 \%$ and $0.5 \%$ higher based on WRF. It cannot be concluded what is the truth, but the WRF results at Hainan seems to overestimate the wind speed.
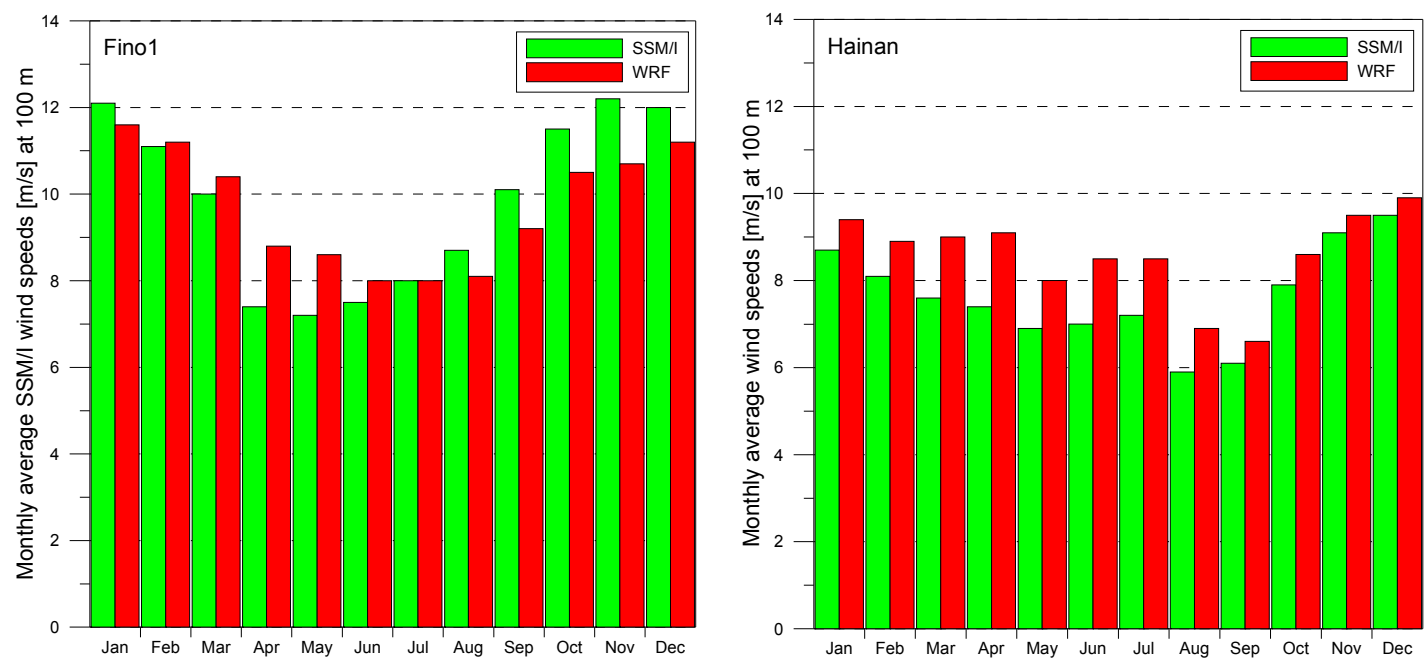

Figure 7. Average monthly SSM/I and WRF wind speeds at $100 \mathrm{~m}$ for 26 years from 1988 to 2013 for Fino1 (left) and Hainan (right), except WRF at Hainan is from 1989 to 2013.
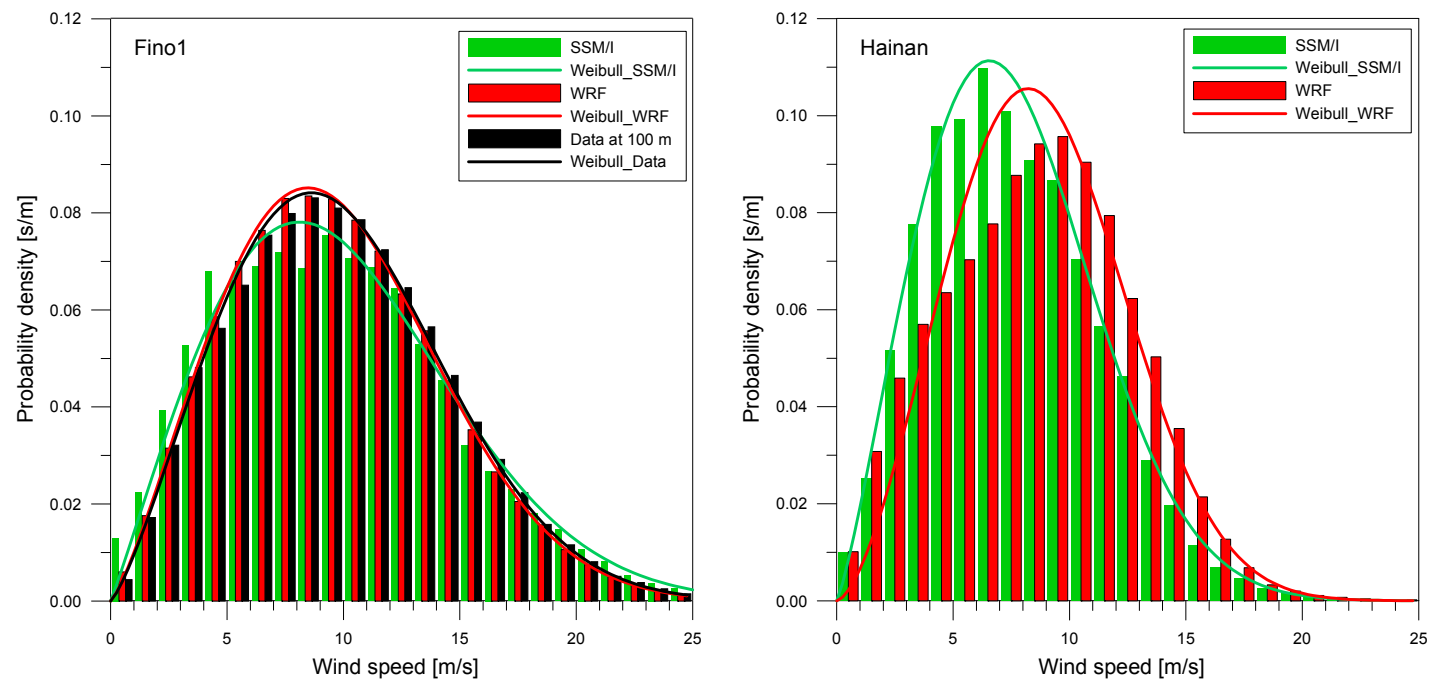

Figure 8. SSM/I- and WRF-derived wind speed distributions and related Weibull curves at $100 \mathrm{~m}$ for: Fino1 (1988-2013) (left); and Hainan (1988-2013, except WRF is 1989-2013) (right). For Fino1, meteorological observations and related Weibull curve at $100 \mathrm{~m}$ for 2004-2013 are also included. 
Table 3. Wind resource statistics at $100 \mathrm{~m}$ calculated from SSM/I and WRF from 1988 to 2013 for Fino1 and Hainan (except WRF 1989 to 2013).

\begin{tabular}{ccccccc}
\hline & \multicolumn{2}{c}{ Fino1 } & & \multicolumn{2}{c}{ Hainan } \\
\cline { 2 - 3 } \cline { 5 - 6 } & SSM/I & WRF & & SSM/I & WRF \\
\hline Mean wind speed $(\mathrm{m} / \mathrm{s})$ & 9.78 & 9.69 & & 7.58 & 8.57 \\
Std. dev. wind speed $(\mathrm{m} / \mathrm{s})$ & 0.45 & 0.38 & & 0.33 & 0.42 \\
Inter-annual variability $(\%)$ & 4.6 & 4.0 & & 4.4 & 4.9 \\
Weibull $A(\mathrm{~m} / \mathrm{s})$ & 11.21 & 10.97 & & 8.56 & 9.90 \\
Weibull $k(-)$ & 2.06 & 2.26 & & 2.22 & 2.62 \\
Energy density $\left(\mathrm{W} / \mathrm{m}^{2}\right)$ & 1131 & 975 & & 470 & 648 \\
\hline
\end{tabular}

The variation in wind speed during the day is examined. From Figure 3 it is clear that wind speeds from SSM/I during some parts of day $(\sim 14 \mathrm{~h})$ get weighted more while winds during other parts of the day $(\sim 10 \mathrm{~h})$ are not included. Figure 9 shows the 6-min bin averaged wind speed from SSM/I at Fino1 and Hainan. In times with less than 20 observations, the values are excluded in the graphics, but the analysis is carried out on all the available data. There are a very few values that show unexpected high wind speed at the edge of the satellite swath, but these few data cannot influence the results to any extent.

The WRF hourly averaged wind speeds at Fino1 for 26 years and at Hainan for 25 years are also shown. At Fino1, SSM/I and WRF wind speeds agree well during the afternoon but WRF wind speeds are slightly lower during the morning. The diurnal wind speed cycle shows only weak variation. At Hainan, SSM/I winds are lower than those from WRF at all times. The diurnal wind speed cycle is significant but the data from SSM/I and WRF do not fully agree on the timing. It should be noted that relatively few SSM/I samples are available at Hainan. Only in the periods 6:00 a.m.-9:00 a.m. and 6:00 p.m. $-9: 00$ p.m. are more than 200 samples available.
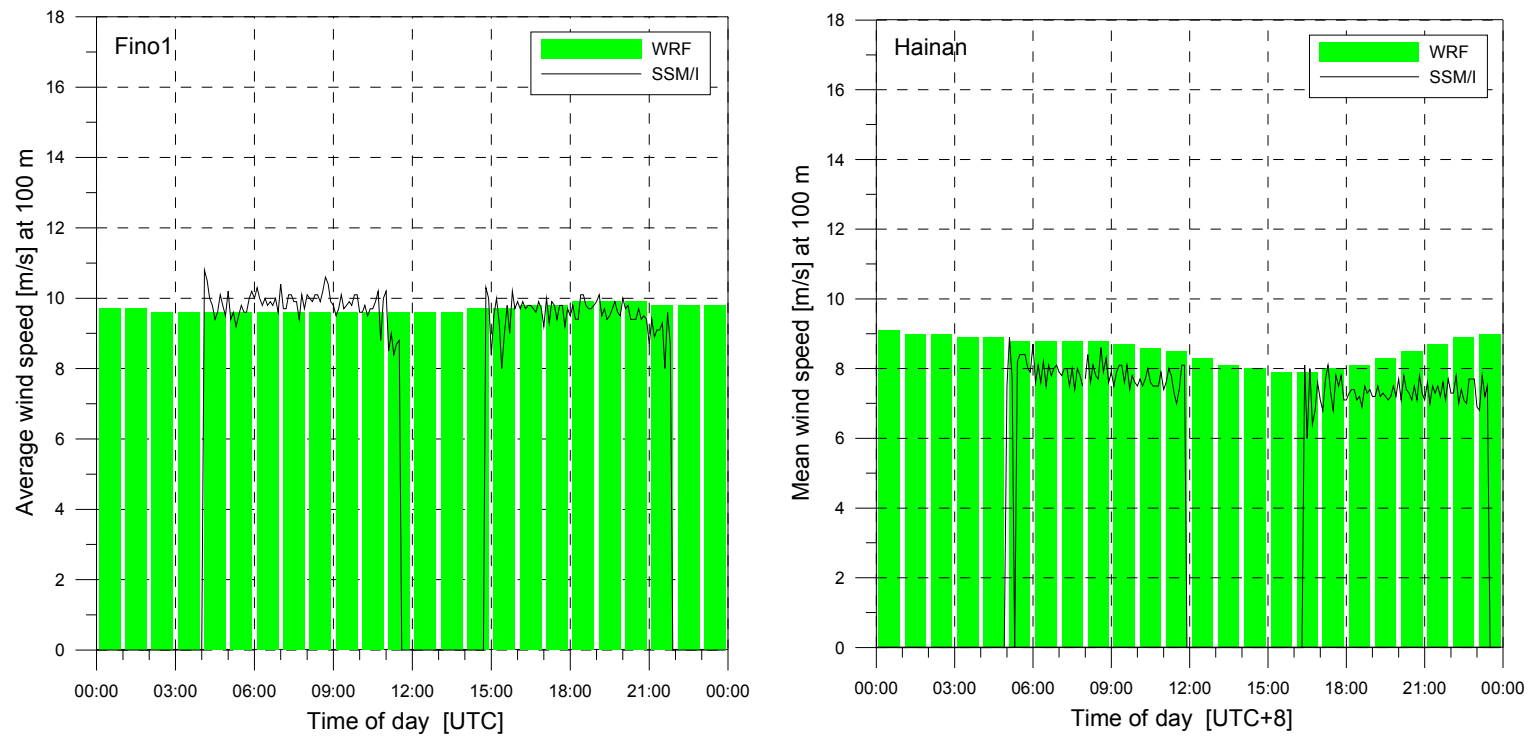

Figure 9. Diurnal wind speed from SSM/I averaged for each registered time point (6-min bins) during 26 years (1988-2013) for Fino1 (left) and hourly values from WRF during same years and Hainan (right) but without year 1988 from WRF.

\subsection{Seasonal Wind Speed Trend Results}

Seasonal trends in wind speed show changes of the windy seasons within the year and thus indicate the timing of expected wind power, which is relevant to compare to societal demand for 
electricity. In the seasonal trend tests, we examine if there is a trend from one January to another January, and from one February and to another February, and so on. The monthly trends are calculated for the $100 \mathrm{~m}$ wind speed from SSM/I for Fino1 and Hainan. The plots in Figure 10 are divided such that the seasonal trade wind pattern in the South China Sea stands out clearly. This is consistent with the distinct seasonal cycle of monsoon progression with lower values in the summer season and higher winds speeds in the winter season. Similar months are selected for the North Sea.

As seen in Figure 10 for Fino1 and Hainan, the monthly averages wind speed values at $100 \mathrm{~m}$ vary very much from year to year; thus the trends, represented by first order regression lines, may be rather speculative. The linear trends in monthly wind speed with statistical significance above the $95 \%$ confidence level at Fino1 are for February based on SSM/I $-0.92 \mathrm{~m} / \mathrm{s}$ per decade and for June $0.56 \mathrm{~m} / \mathrm{s}$ per decade. This result is interpreted as strong winter winds ending one month earlier during recent 26 years. In other words, mild spring winds arrive one month earlier and stronger winds occur in June.
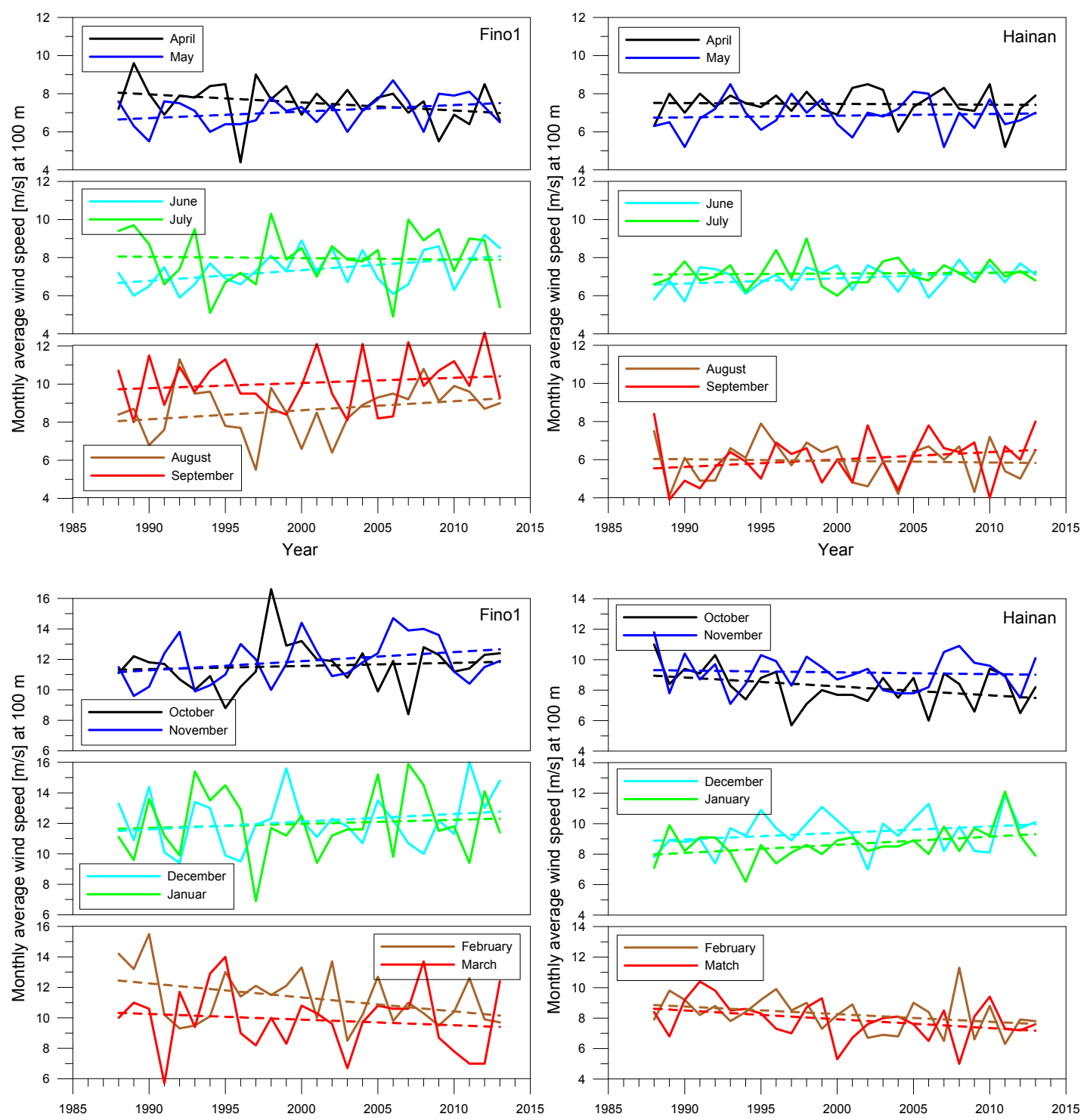

Figure 10. Monthly averages of SSM/I wind speeds at $100 \mathrm{~m}$ as function of year for 1988 to 2013 for: Fino1 (left); and Hainan (right). Dashed lines indicate the calculated trends.

To investigate the trend further, the $95 \%$ percentile wind speed trend is calculated. The average wind speed trend and the $95 \%$ percentile wind speed trend as well as the statistical significance 
levels are graphed in Figure 11. For Fino1 the 95\% percentile wind speed trend in June is $1 \mathrm{~m} / \mathrm{s}$ per decade with high statistical significance and in February it is $-0.94 \mathrm{~m} / \mathrm{s}$ per decade slightly below the $90 \%$ confidence level. The average wind speed trend and the $95 \%$ percentile wind speed trend show similar behavior for all months.

At Hainan, only the $95 \%$ percentile wind speed trend show statistical significance above $95 \%$. It is for winds in June with trend $0.57 \mathrm{~m} / \mathrm{s}$ per decade. The average wind speed trend is positive in June at $0.27 \mathrm{~m} / \mathrm{s}$ per decade and negative in February, March and October at around $-0.55 \mathrm{~m} / \mathrm{s}$ per decade at the $90 \%$ confidence level. The average wind speed trend and $95 \%$ percentile wind speed trend do not follow each other as closely at Hainan as at Fino1.
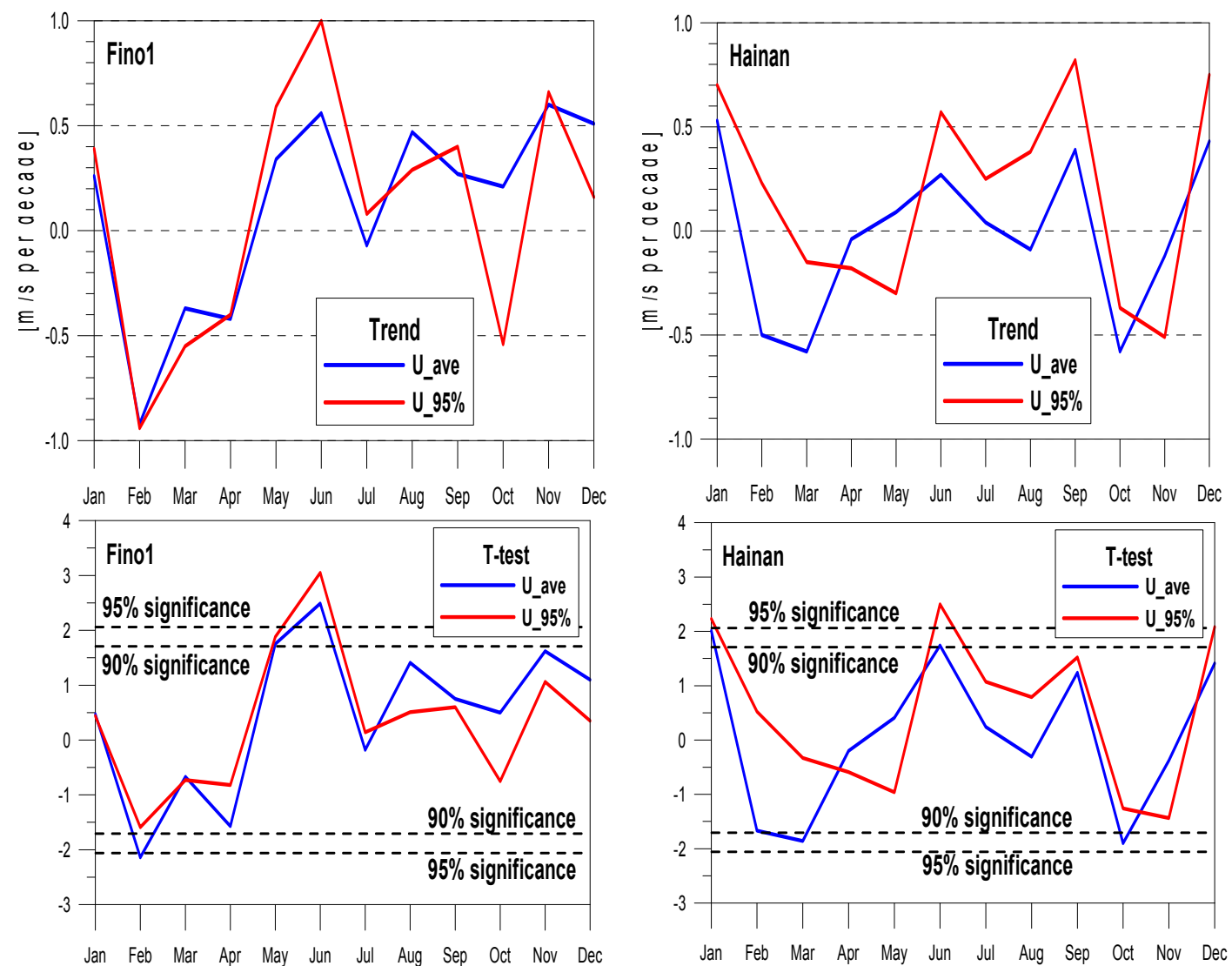

Figure 11. The average wind speed trend and the $95 \%$ percentile wind speed trend based on SSM/I wind speeds at $100 \mathrm{~m}$ as function of year for 1988 to 2013 for: Fino1 (top left); and Hainan (top right) and significance test. Dashed lines indicate the calculated significance levels for: Fino1 (bottom left); and Hainan (bottom right).

\subsection{Yearly Wind Speed Trend Results}

The yearly average trend is of great interest because it is related to the potential changes in wind turbine energy production during a project lifetime. The annual energy production is key information in wind farming as the economical revenue is closely related to it. Figure 12 shows the yearly wind speed averages and the $95 \%$ percentile wind speed trends from SSM/I at Fino1 and Hainan including linear trend lines. At Fino1 the average wind speed trend is $0.1 \mathrm{~m} / \mathrm{s}$ per decade and at Hainan $0.04 \mathrm{~m} / \mathrm{s}$ per decade but none of these positive trends are significant at the 95\% confidence level. At Fino1 also yearly averaged and 95\% percentile wind speeds (2004-2013) are included in Figure 12, but the series is too short for trend analysis. The meteorological data show lower 95\% percentile values than SSM/I. 

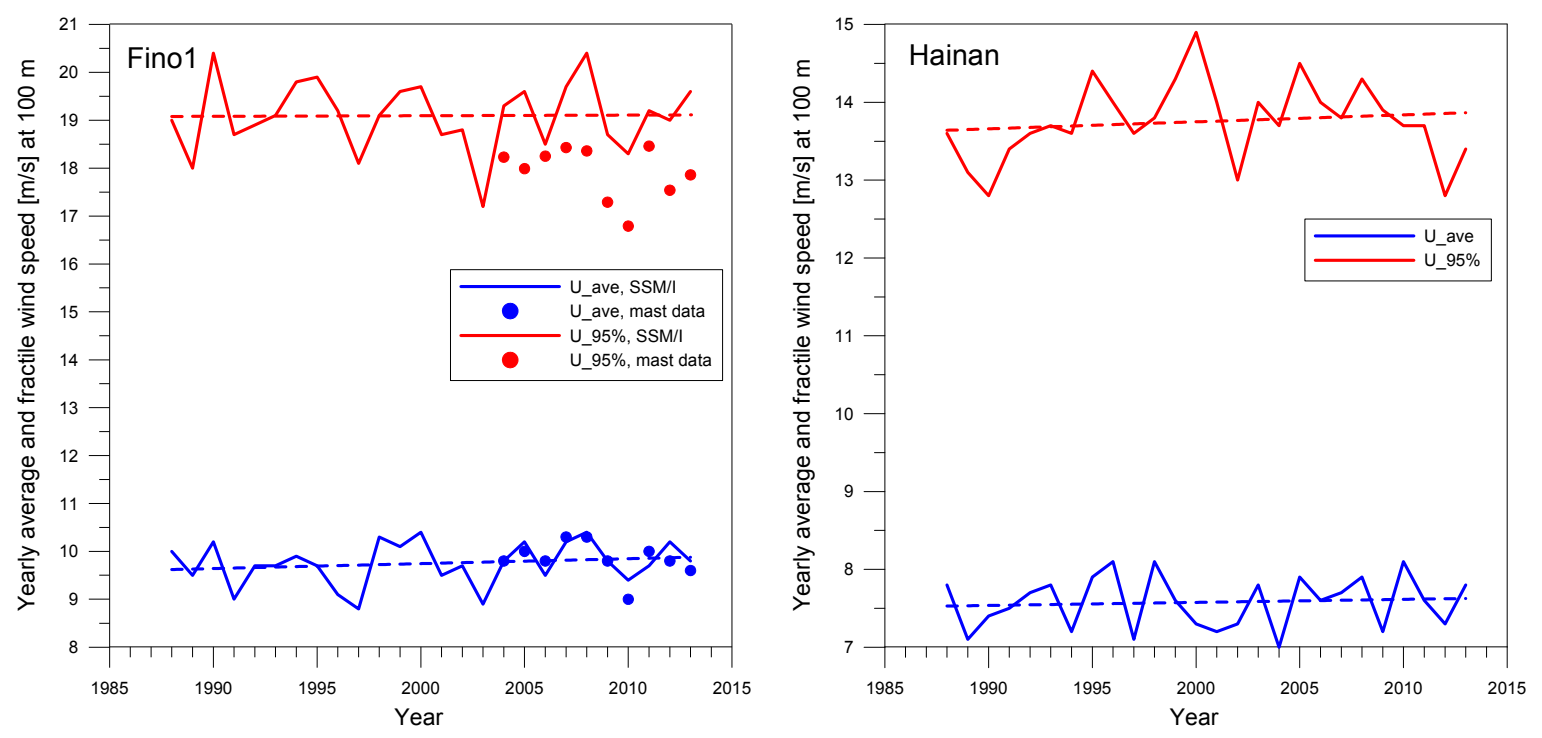

Figure 12. Yearly averages and the $95 \%$ percentile wind speed trends of SSM/I at $100 \mathrm{~m}$ at Fino1 (1988-2013) and in-situ observations (left); and (right) Hainan SSM/I (1988-2013). Dashed lines indicate the calculated trends.

\section{Discussion}

The quarter-century wind speed statistics for the North Sea and South China Sea relevant for wind energy planning are examined. Wind derived from SSM/I vs. Fino1 data have $R^{2} 0.72$ and std. dev. $1.75 \mathrm{~m} / \mathrm{s}$ and mean difference $-0.12 \mathrm{~m} / \mathrm{s}$ at $100 \mathrm{~m}$. Better agreement is found for SSM/I vs. WRF at $10 \mathrm{~m}$ with $R^{2} 0.88$, std. dev. $0.98 \mathrm{~m} \cdot \mathrm{s}^{-1}$ and mean difference $-0.12 \mathrm{~m} / \mathrm{s}$. For the $10 \mathrm{~m}$ winds, the comparison is very good. This is despite the fact that SSM/I are equivalent neutral winds and WRF stability-dependent winds. Our analysis based on WRF show near-neutral conditions. Other studies [26,38] show the atmospheric stratification at Fino1 is near neutral towards slightly stable. It means that WRF-simulated real winds are expected to be slightly higher than SSM/I equivalent neutral winds.

At $100 \mathrm{~m}$ height, the average wind speed from SSM/I during 26 years based on 45,146 observations is $9.75 \mathrm{~m} / \mathrm{s}$ and based on 227,760 WRF (hourly) results is $9.68 \mathrm{~m} / \mathrm{s}$. It may be by chance that a negative mean difference is seen, as the difference is less than $1 \%$. A possible cause is the position of the SSM/I grid cell, which is shifted slightly further offshore where winds are expected to be (slightly) higher than at the meteorological mast. Another reason for SSM/I winds to be slightly higher could be land contamination of SSM/I data observed relatively near the coast (around $60 \mathrm{~km}$ for Fino1 and $200 \mathrm{~km}$ for Hainan). The safe zone is around three times $3 \mathrm{~dB}$ beam size from which $98 \%$ on-Earth radiance originates. This corresponds to an ellipse of size $207 \mathrm{~km}$ by $129 \mathrm{~km}$ at $19 \mathrm{GHz}$ for SSM/I. The land has much higher brightness temperature than ocean and therefore even small fractions of land will result in too high winds [42]. The coastal mask seems to be suitable at Fino1. The above results provide confidence in using SSM/I winds for long-term wind resource statistics for this region.

In the South China Sea, SSM/I- and WRF-derived wind speeds are compared. At the Hainan study site at $10 \mathrm{~m} \mathrm{R} R^{2}$ is 0.71 , std. dev. $1.10 \mathrm{~m} / \mathrm{s}$ and mean difference $0.83 \mathrm{~m} / \mathrm{s}$ while the statistics at $100 \mathrm{~m}$ are $R^{2} 0.67$, std. dev. $1.41 \mathrm{~m} / \mathrm{s}$ and mean difference $0.83 \mathrm{~m} / \mathrm{s}$. It may be noted that the mean difference is high for these collocated samples. The average wind speed at $100 \mathrm{~m}$ from 26 years of $\mathrm{SSM} / \mathrm{I}$ observations is $7.58 \mathrm{~m} / \mathrm{s}$ whereas 25 years of data from WRF is $8.53 \mathrm{~m} / \mathrm{s}$, i.e., $11 \%$ difference. One year less data from WRF than SSM/I is unlikely to explain the difference. The SSM/I-derived winds are equivalent neutral winds and our extrapolation to $100 \mathrm{~m}$ did not include a stability correction. This means that SSM/I winds at $100 \mathrm{~m}$ are expected to be positively biased (overestimated) as the climatology of stability at Hainan is dominated by unstable to neutral stratification. From our stability 
analysis the bias on mean wind speed is estimated as $0.5 \mathrm{~m} / \mathrm{s}$. Different reanalysis (ERA Interim vs. CFSR), horizontal grid spacing, and PBL schemes (YSU vs. MYJ) are used in the WRF simulations over the North and South China Sea. While little sensitive to these two factors in the North Sea [29], the impact is unknown over the South China Sea. It is not possible to conclude whether SSM/I or WRF are more reliable. We note that for Hainan the WRF monthly mean wind speeds and distribution are systematically higher than SSM/I.

Comparison of point observations vs. spatial data from satellites has well-known scaling issue. The surface-layer theory offers weighting functions, traditionally called footprints, for scaling between the upwind area and the measurement point at a certain height $[43,44]$. Assuming homogenous and stationary conditions the observed winds will be mainly related to the upwind near-field area of the footprint. In other words, the time-averaged winds from observations, e.g., as we use hourly values, compare to an upwind area in the spatial domain. For $10 \mathrm{~m}$ winds, the area will be smaller than for winds observed at $100 \mathrm{~m}$. The two sites investigated in this study are relatively far from sharp horizontal wind speed gradients, which otherwise would limit the analysis $[23,45]$.

The seasonal wind speed trend at Fino1 in February $(-0.92 \mathrm{~m} / \mathrm{s}$ per decade) is statistically significant at the $95 \%$ significance level and in June $(0.56 \mathrm{~m} / \mathrm{s}$ per decade). The $95 \%$ percentile wind speeds trend $(1.0 \mathrm{~m} / \mathrm{s}$ per decade) in June is statistically significant at the $95 \%$ level. The trends in average wind speeds and 95\% percentile winds are similar at Fino1 for all months. Large-scale climate dynamics such as NAO most likely dominate the wind speed trends.

At Hainan the $95 \%$ percentile wind speed trend $(0.57 \mathrm{~m} / \mathrm{s}$ per decade) show statistical significance above $95 \%$ in June. At the $90 \%$ confidence level the average wind speed trend is positive $(0.27 \mathrm{~m} / \mathrm{s}$ per decade) in June and negative in February, March and October (around $-0.55 \mathrm{~m} / \mathrm{s}$ per decade). The average wind speed trend and 95\% percentile wind speed trend follow each other from June to January but not from February to May at Hainan. As stated earlier decadal trend analysis based on SSM/I should be possible for trends in wind speed above $0.1 \mathrm{~m} / \mathrm{s}$ per decade while WRF may show artificial trends due to inconsistency in time due to changes in available input used in the driving reanalysis [1] and are therefore not used for trend analysis in the current study.

Neither in the North Sea, nor in the South China Sea does the current analysis show significant wind speed trends based on 26 years of observations from SSM/I from 1988 to 2013 at the $95 \%$ confidence level. The meteorological wind speed observations across China show significant decreasing trends [13] among several other studies. Decreasing winds over land are likely a consequence of land cover changes, e.g., urbanization near meteorological masts. However, it is remarkable that our results on decadal wind speed trends in the South China Sea do not show similar pattern, as the interpretation for the changes in wind speed are large-scale dynamics $[5,6,13,46]$. Our results based on SSM/I shows weak positive trends at Fino1 $(0.10 \mathrm{~m} / \mathrm{s}$ per decade $)$ and Hainan $(0.04 \mathrm{~m} / \mathrm{s}$ per decade) but these trend values are not significant at the $95 \%$ confidence level. Several other studies have found positive trend in wind speeds over the open ocean with statistically significant values [6-9].

Wind resource statistics at $100 \mathrm{~m}$ based on SSM/I and WRF at Fino1 show good agreement for mean wind speed (less than 1\% difference) while the energy density differs around 14\%. At Fino1 estimation of energy density at $100 \mathrm{~m}$ from mast data shows $1002 \mathrm{~W} / \mathrm{m}^{2}$ from September 2003 to August 2007 (4 years) with the average energy density for each full year $870 \mathrm{~W} / \mathrm{m}^{2}, 1077 \mathrm{~W} / \mathrm{m}^{2}$, $836 \mathrm{~W} / \mathrm{m}^{2}$ and $1225 \mathrm{~W} / \mathrm{m}^{2}$ [47]. The temporal yearly variability is high. The energy density based on SSM/I extrapolated to $100 \mathrm{~m}$ is $1131 \mathrm{~W} / \mathrm{m}^{2}$ whereas WRF is $975 \mathrm{~W} / \mathrm{m}^{2}$ for 26 years. It seems likely that the SSM/I estimate for Fino1 is too high, which in part also may be explained from the SSM/I grid position being shifted slightly further offshore than the actual mast or SSM/I is influenced by land contamination. The observations at Fino1 for a much shorter period (10 years vs. 26 years) show Weibull distribution closer to WRF than to SSM/I. No firm conclusion can be drawn as to which energy density is correct. 
In the South China Sea, in-situ observations are not available. Available estimates of wind resources in the South China Sea include results from one year (2011) showing strong gradients in wind energy density near Hainan $\sim 500 \mathrm{~W} / \mathrm{m}^{2}$ at $100 \mathrm{~m}$ [23]. Maps on the offshore wind energy density are presented in [48] based on [49] and the International Energy Agency (IEA) and Energy Research Institute [50]. The spatial patterns in these maps are dissimilar. Near Hainan the values are around $400 \mathrm{~W} / \mathrm{m}^{2}$ and $450 \mathrm{~W} / \mathrm{m}^{2}$, respectively. The data source for production is not described nor is its years, height or method. Our results on wind energy density from SSM/I and WRF vary considerably. At Hainan, the WRF-derived means show higher values $648 \mathrm{~W} / \mathrm{m}^{2}$ while SSM/I show $470 \mathrm{~W} / \mathrm{m}^{2}$, i.e., around 30\% difference. The WRF values are likely overestimated. One indication is the diurnal wind speed variation (Figure 9) where SSM/I and WRF show clear diurnal variation but with WRF winds consistently higher than SSM/I. Lack of wind speed observations from SSM/I during several hours each day may be more problematic near Hainan than in the North Sea as the diurnal winds are more variable in the South China Sea. SSM/I are equivalent neutral winds and extrapolated to $100 \mathrm{~m}$ using neutral wind profile. We expect the energy density from SSM/I to be overestimated near Hainan because the atmosphere is often unstable and our analysis on stability shows around $0.5 \mathrm{~m} / \mathrm{s}$ lower winds at $100 \mathrm{~m}$ using stability correction than if assuming neutral conditions.

\section{Conclusions}

In summary, SSM/I and WRF results are compared in both study areas. The analysis of SSM/I observations is straightforward and the Charnock relationship and the logarithmic profile method have been used to extrapolate the winds to $100 \mathrm{~m}$. The WRF model is a strong tool for wind resource assessment. Many more parameters than wind speed are available from model results, e.g., stability, temperature, etc. However, the accuracy of the results has to be checked versus reliable observations to ensure optimal choice of initial and boundary conditions and physical parameterizations. The number of possible choices in model set up is overwhelmingly large and even though computational power has increased rapidly, there is continued need for research and comparison analysis, in particular, over ocean. The winds in the North Sea (predominantly westerly's coming from the North Atlantic Sea) are relatively simpler to simulate than those in the South China Sea, which are influenced by many different large-scale, seasonal (e.g., monsoon) and mesoscale phenomena. SSM/I can be used for consistency check of model results, e.g., when in-situ observations are too few for extensive model evaluation and the choice of planetary boundary layer scheme [29].

$\mathrm{SMM} / \mathrm{I}$ surface ocean wind observations provide new insight to offshore wind statistics relevant for wind energy planning. Novel results presented here are the seasonal wind pattern with springtime winds arriving one month earlier at Fino1 in the North Sea from 1988 to 2013 and higher winds in June. The results are based on SSM/I wind speeds extrapolated from $10 \mathrm{~m}$ to $100 \mathrm{~m}$ using Charnock and a logarithmic wind profile, thus equivalent neutral winds. The weekly average SSM/I values are successfully compared to WRF model results (better at $10 \mathrm{~m}$ than $100 \mathrm{~m}$ ) and Fino1 mast data of stability-dependent winds. The SSM/I observations do not show significant decadal wind speed changes at quarter-century timescale. The inter-annual variability is $4.6 \%$ based on SSM/I and $4.0 \%$ based on WRF at Fino1.

At Hainan, in the South China Sea, SSM/I and WRF wind speeds also correlate well (better at $10 \mathrm{~m}$ than $100 \mathrm{~m}$ ) but there is a bias of overestimated wind speeds in WRF. This is despite the fact that the climatology of atmospheric stratification is mainly unstable, and it is therefore expected that SSM/I equivalent neutral winds would be bias high using Charnock and a logarithmic profile approach used to extrapolate the winds from $10 \mathrm{~m}$ to $100 \mathrm{~m}$. The stability analysis based on WRF output and adaptation of the Monin-Obukhov similarity theory show unstable conditions with around $0.5 \mathrm{~m} / \mathrm{s}$ lower mean wind speed. The energy density varies across the South China Sea but the absolute level is not certain from this analysis. There is no significant trend found in wind speeds during the 26 years; however, seasonal changes are observed with negative trend in February, March and October and positive trend in June. 
Acknowledgments: We grateful acknowledge observations from SSM/I produced by Remote Sensing Systems and sponsored by the NASA Earth Science REASoN DISCOVER Project with data available at www.remss.com; Meteorological data from the Fino1 platform from Bundesamt für Seeschifffart und Hydrographie (BSH); and funding for the project "Study on Offshore Wind Resource Assessment Based on Satellite Data and Modeling (ORES)" from the Sino-Danish Renewable Energy Development Programme Danida file reference number 104.Kina.1.MFS.4-1-2-2 is kindly acknowledged. We are thankful for positive engagement from CNREC.

Author Contributions: Charlotte Bay Hasager conceived the project and wrote the article; Poul Astrup analyzed the SSM/I and WRF data and produced results and graphics; Rong Zhu and Chang Rui performed WRF runs for China; Merete Badger contributed on work plan and remote sensing; and Andrea N. Hahmann performed WRF runs for Northern Europe.

Conflicts of Interest: The authors declare no conflict of interest.

\title{
Appendix A
}

The LINearized COMputational (LINCOM) model [51,52] has been used to calculate the variation of the roughness at the sea and the corresponding Charnock coefficient as a function of wind speed at $10 \mathrm{~m}$ and fetch (in $\log 10 \mathrm{scale}$ ). Figure A1 shows the results. At Fino1, the shortest fetch is $40 \mathrm{~km}$ ( $\log 10$ is 4.6 ), thus, for winds up to $11 \mathrm{~m} / \mathrm{s}$, the Charnock open water 0.011 is valid and for all other important directions the fetch is $80 \mathrm{~km}$ ( $\log 10$ is 4.9 ) or longer, thus 0.011 is valid until $17 \mathrm{~m} / \mathrm{s}$. At Fino1, $97.3 \%$ of all SSM/I winds are below $17 \mathrm{~m} / \mathrm{s}$. At Hainan, the fetch is even longer in all directions and practically all winds are below $17 \mathrm{~m} / \mathrm{s}$. We find it acceptable to use Charnock open water 0.011 at both sites for extrapolation of winds from 10 to $100 \mathrm{~m}$.

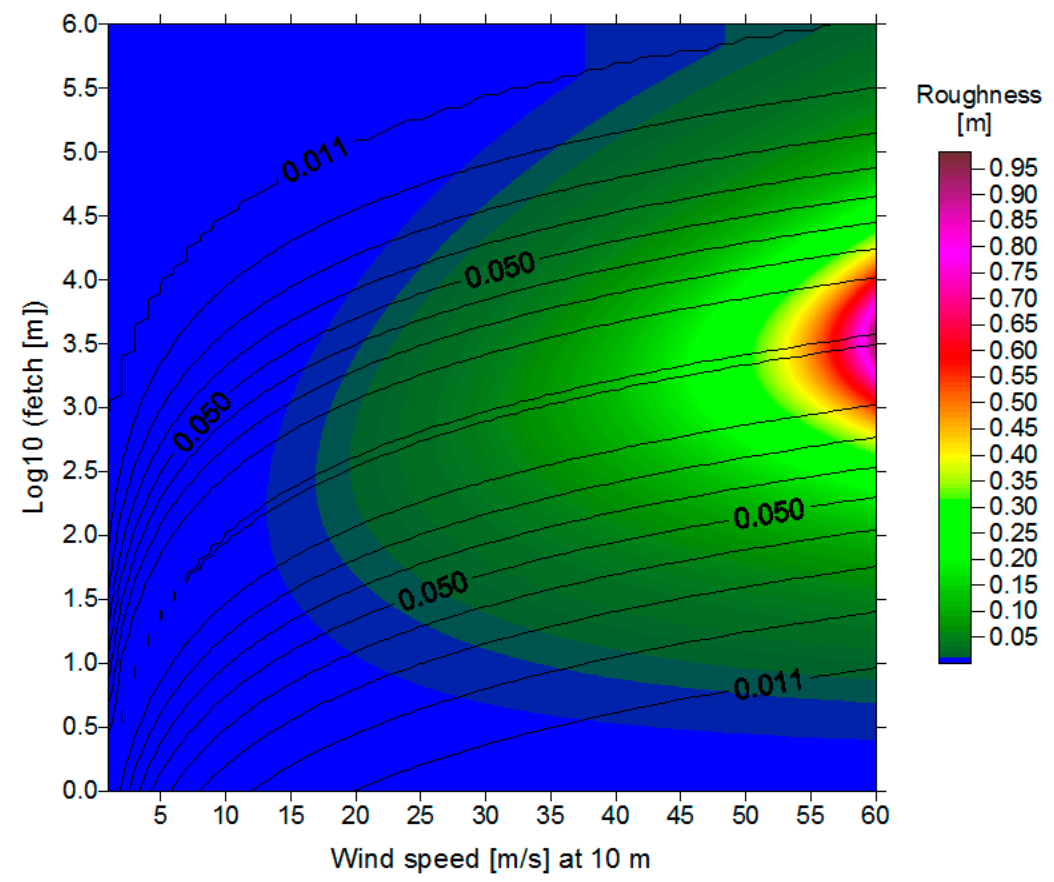

Figure A1. LINCOM model results of the roughness at the sea as function of wind speed at $10 \mathrm{~m}$ and fetch (shown in $\log 10$ scale) and overlaid with the corresponding Charnock coefficient in contour lines.

\author{
Abbreviations \\ AGL \\ AMSL \\ ARW \\ CCMP \\ CFSR \\ DTU \\ ICOADS \\ IFREMER-BWF \\ Above Ground Level \\ Above Mean Sea Level \\ Advanced Research WRF \\ Cross-Calibrated Multi-Platform Ocean Surface wind Vectors \\ Climate Forecast System Reanalysis \\ Technical University of Denmark \\ International Comprehensive Ocean-Atmosphere Data Set \\ French Research Institute for the Exploitation of the Sea Blended Wind Fields
}




$\begin{array}{ll}\text { LST } & \text { Local Standard Time } \\ \text { MYJ } & \text { Mellor-Yamada-Janjic } \\ \text { NCEP } & \text { National Centers for Environmental Prediction } \\ \text { NOAA } & \text { National Oceanic and Atmospheric Administration } \\ \text { OISST } & \text { Optimum Interpolation Sea Surface Temperature } \\ \text { PBL } & \text { Planetary Boundary Layer } \\ \text { SAR } & \text { Synthetic Aperture Radar } \\ \text { SSM/I } & \text { Special Sensor Microwave Imager } \\ \text { SSM/IS } & \text { Special Sensor Microwave Imager Sounder } \\ \text { WAsP } & \text { Wind Atlas Analysis and Application Program } \\ \text { WRF } & \text { Weather Research and Forecasting } \\ \text { YSU } & \text { Yonsei University }\end{array}$

\section{References}

1. Larsén, X.G.; Mann, J. Extreme Winds from the NCEP/NCAR Reanalysis Data. Wind Energy 2009, 12, 556-573. [CrossRef]

2. Liléo, S.; Berge, E.; Undheim, O.; Klinkert, R.; Bredesen, R.E. Long-term correction of wind measurements. State-of-the-art, guidelines and future work. In Proceedings of the European Wind Energy Association (EWEA) Conference, Vienna, Austria, 4-7 February 2013.

3. Woodruff, S.D.; Worley, S.J.; Lubker, S.J.; Ji, Z.; Freeman, J.E.; Berry, D.I.; Brohan, P.; Kent, E.C.; Reynolds, R.W.; Smith, S.R.; et al. ICOADS release 2.5 and data characteristics. Int. J. Climatol. 2010, 31, 951-967. [CrossRef]

4. Woodruff, S.D.; Slutz, R.J.; Jenne, R.L.; Steurer, P.M. A comprehensive ocean atmosphere dataset. Bull. Am. Meteorol. Soc. 1987, 68, 1239-1250. [CrossRef]

5. Tokinaga, H.; Xie, S.P. Wave- and anemometer-based sea surface wind (WASWind) for climate change analysis. J. Clim. 2011, 24, 267-285. [CrossRef]

6. Wentz, F.J.; Ricciardulli, L.; Hilburn, K.; Mears, C. How much more rain will global warming bring? Science 2007, 317, 233-235. [CrossRef] [PubMed]

7. Young, I.R.; Zieger, S.; Babanin, A.V. Global trends in wind speed and wave height. Science 2011, 332, 451-455. [CrossRef] [PubMed]

8. Wentz, F.J.; Ricciardulli, L. Comment on "Global Trends in Wind Speed and Wave Height". Science 2011, 334, 905-905. [CrossRef] [PubMed]

9. Young, I.R.; Babanin, A.V.; Zieger, S. Response to Comment on "Global Trends in Wind Speed and Wave Height". Science 2011, 334, 905. [CrossRef]

10. Pryor, S.C.; Barthelmie, R.J.; Schoof, J.T. Past and future wind climates over the contiguous USA based on the North American Regional Climate Change Assessment Program model suite. J. Geophys. Res. 2012, 117, D19119. [CrossRef]

11. Pryor, S.C.; Barthelmie, R.J.; Kjellström, E. Potential climate change impact on wind energy resources in northern Europe: Analyses using a regional climate model. Clim. Dyn. 2005, 25, 815-835. [CrossRef]

12. Früh, W.G. Long-term wind resource and uncertainty estimation using wind records from Scotland as example. Renew. Energy 2013, 50, 1014-1026. [CrossRef]

13. Chen, L.; Li, D.; Pryor, S.C. Wind speed trends over China: Quantifying the magnitude and assessing causality. Int. J. Climatol. 2013, 33, 2579-2590. [CrossRef]

14. Capps, S.B.; Zender, C.S. Estimated global ocean wind power potential from QuikSCAT observations, accounting for turbine characteristics and siting. J. Geophys. Res. 2010, 115, D09101. [CrossRef]

15. Liu, W.T.; Tang, W.; Xie, X. Wind power distribution over the ocean. Geophys. Res. Lett. 2008, 35, L13808. [CrossRef]

16. 4C Offshore. Available online: http://www.4coffshore.com/offshorewind/ (accessed on 12 June 2016).

17. Karagali, I.; Badger, M.; Hahmann, A.N.; Peña, A.; Hasager, C.B.; Sempreviva, A.M. Spatial and temporal variability in winds in the Northern European Seas. Renew. Energy 2013, 57, 200-210. [CrossRef]

18. Karagali, I.; Peña, A.; Badger, M.; Hasager, C.B. Wind characteristics in the North and Baltic Seas from the QuikSCAT satellite. Wind Energy 2014, 17, 123-140. [CrossRef]

19. Chen, X.Y.; Pan, D.L.; He, X.Q.; Bai, Y.; Wang, Y.F.; Zhu, Q.K. Seasonal and inter-annual variability of sea surface wind over the China seas and its adjacent ocean from QuikSCAT and ASCAT data during 2000-2011. Proc. SPIE 2012, 8532. [CrossRef] 
20. Jiang, D.; Zhuang, D.F.; Huang, Y.H.; Wang, J.H.; Fu, J.Y. Evaluating the spatiotemporal variation of China's offshore wind resources based on remotely sensed wind field data. Renew. Sustain. Energy Rev. 2013, 24, 142-148. [CrossRef]

21. Badger, M.; Badger, J.; Nielsen, M.; Hasager, C.B.; Peña, A. Wind class sampling of satellite SAR imagery for offshore wind resource mapping. J. Appl. Meteorol. Climatol. 2010, 49, 2474-2491. [CrossRef]

22. Hasager, C.B.; Mouche, A.; Badger, M.; Bingöl, F.; Karagali, I.; Driesenaar, T.; Stoffelen, A.; Peña, A.; Longépé, N. Offshore wind climatology based on synergetic use of Envisat ASAR, ASCAT and QuikSCAT. Remote Sens. Environ. 2015, 156, 247-263. [CrossRef]

23. Chang, R.; Zhu, R.; Badger, M.; Hasager, C.B.; Xing, X.; Jiang, Y. Offshore Wind Resources Assessment from Multiple Satellite Data and WRF Modeling over South China Sea. Remote Sens. 2015, 7, 467-487. [CrossRef]

24. Wentz, F.J. SSM/I Version-7 Calibration Report; Report Number 011012; Remote Sensing Systems: Santa Rosa, CA, USA, 2013; pp. 1-46.

25. Charnock, H. Wind stress on a water surface. Q. J. R. Meteorol. Soc. 1955, 81, 639-640. [CrossRef]

26. Peña, A.; Mikkelsen, T.; Gryning, S.E.; Hasager, C.B.; Hahmann, A.N.; Badger, M.; Karagali, I.; Courtney, M. Offshore Vertical Wind Shear: Final Report on NORSEWInD's Work Task 3.1; DTU Wind Energy: Roskilde, Denmark, 2012; pp. 1-116.

27. Badger, M.; Peña, A.; Hahmann, A.N.; Mouche, A.; Hasager, C.B. Extrapolating satellite winds to turbine operating heights. J. Appl. Meteorol. Climatol. 2016, 55, 975-991. [CrossRef]

28. Hasager, C.B.; Stein, D.; Courtney, M.; Peña, A.; Mikkelsen, T.; Stickland, M.; Oldroyd, A. Hub height ocean winds over the North Sea observed by the NORSEWInD lidar array: Measuring techniques, quality control and data management. Remote Sens. 2013, 5, 4280-4303. [CrossRef]

29. Hahmann, A.N.; Vincent, C.L.; Peña, A.; Lange, J.; Hasager, C.B. Wind climate estimation using WRF model output: Method and model sensitivities over the sea. Int. J. Climatol. 2015, 35, 3422-3439. [CrossRef]

30. Skamarock, W.C.; Klemp, J.B.; Dudhia, J.; Gill, D.O.; Barker, D.M.; Wang, W.; Powers, J.G. A Description of the Advanced Research WRF, Version 3; National Center for Atmospheric Research: Boulder, CO, USA, 2008.

31. Carvalho, D.; Rocha, D.; Gómez-Gesteira, M.; Silva Santos, C. Comparison of reanalyzed, analyzed, satellite-retrieved and NWP modelled winds with buoy data along the Iberian Peninsula coast. Remote Sens. Environ. 2014, 152, 480-492. [CrossRef]

32. Dee, D.P.; Uppala, S.M.; Simmons, A.J.; Berrisford, P.; Poli, P.; Kobayashi, S.; Andrae, U.; Balmaseda, M.A.; Balsamo, G.; Bauer, P.; et al. The ERA-Interim reanalysis: Configuration and performance of the data assimilation system. Q. J. R. Meteorol. Soc. 2011, 137, 553-597. [CrossRef]

33. Reynolds, R.W.; Smith, T.M.; Liu, C.; Chelton, D.B.; Casey, K.S.; Schlax, M.G. Daily High-Resolution-Blended analyses for sea surface temperature. J. Clim. 2007, 20, 5473-5496. [CrossRef]

34. Hong, S.Y.; Noh, Y.; Dudhia, J. A new vertical diffusion package with an explicit treatment of entrainment processes. Mon. Weather Rev. 2006, 134, 2318-2341. [CrossRef]

35. Saha, S.; Moorthi, S.; Pan, H.L.; Wu, X.; Wang, J.; Nadiga, S.; Tripp, P.; Kistler, R.; Woollen, J.; Behringer, D.; et al. The NCEP climate forecast system reanalysis. Bull. Am. Meteorol. Soc. 2010, 91, 1015-1057. [CrossRef]

36. Mellor, G.L.; Yamada, T. Development of a turbulence closure model for geophysical fluid problems. Rev. Geophys. Space Phys. 1982, 20, 851-875. [CrossRef]

37. Arpaci, V.S.; Larsen, P.S. Convention Heat Transfer; Prentice-Hall, Inc.: Upper Saddle River, NJ, USA, 1984.

38. Peña, A.; Hahmann, A.N. Atmospheric stability and turbulence fluxes at Horns Rev-An intercomparison of sonic, bulk and WRF model data. Wind Energy 2012, 15, 717-731. [CrossRef]

39. Landberg, L. Meteorology for Wind Energy: An Introduction; John Wiley \& Sons: Hoboken, NJ, USA, 2015.

40. Troen, I.; Petersen, E.L. European Wind Atlas; Risø National Laboratory: Roskilde, Denmark, 1989; pp. 1-656.

41. Mortensen, N.; Heathfield, D.N.; Landberg, L.; Rathmann, O.; Troen, I.; Petersen, E.L. Wind Atlas Analysis and Wind Atlas Analysis and Application Program: WAsP 7.0 Help Facility; Risø National Laboratory: Roskilde, Denmark, 2000; pp. 1-277.

42. Yang, J.X.; Mckague, D.S.; Ruf, C.S. Land contamination correction for passive microwave radiometer data: Demonstration of wind retrieval in the Great Lakes using SSM/I. J. Atmos. Ocean. Technol. 2014, 31, 2094-2113. [CrossRef]

43. Hasager, C.B.; Nielsen, M.; Astrup, P.; Barthelmie, R.J.; Dellwik, E.; Jensen, N.O.; Jørgensen, B.H.; Pryor, S.C.; Rathmann, O.; Furevik, B.R. Offshore wind resource estimation from satellite SAR wind field maps. Wind Energy 2005, 8, 403-419. [CrossRef] 
44. Gash, J.H. A note on estimating the effect of a limited fetch on micrometeorological evaporation measurements. Bound. Layer Meteorol. 1986, 35, 409-413. [CrossRef]

45. Barthelmie, R.J.; Badger, J.; Pryor, S.C.; Hasager, C.B.; Christiansen, M.B.; Jørgensen, B.H. Offshore coastal wind speed gradients: Issues for the design and development of large offshore windfarms. Wind Eng. Int. J. Wind Power 2007, 31, 369-382. [CrossRef]

46. Sun, L.; Yu, H.M.; Wang, P. Analysis of the seasonal and interannual variability of sea surface wind in the East China Seas and its adjacent ocean. Mar. Forecasts 2010, 27, 30-37. (In Chinese)

47. Bilstein, M.; Emeis, S. The annual variation of vertical profiles of Weibull parameters and their applicability for wind energy potential. DEWI Mag. 2010, 36, 42-46.

48. Hong, L.; Møller, P. Feasibility study of China's offshore wind target 2020. Energy 2012, 48, $268-277$. [CrossRef]

49. Wang, M. Introduction of China's offshore wind planning. In Proceedings of the Offshore Wind China 2010 Conference and Exhibition, Shanghai, China, 7-9 June 2010.

50. Techology Roadmap China Wind Energy Development Roadmap 2050. Report 2011. Available online: http://www.iea.org/publications/freepublications/publication/china_wind.pdf (accessed on 12 June 2016).

51. Astrup, P.; Larsen, S.E.; Rathmann, O.; Madsen, P.H.; Højstrup, J. WAsP engineering—Wind flow modelling over land and sea. In Wind Engineering into the 21st Century, Proceedings of the 10th International Conference on Wind Engineering, Copenhagen, Denmark, 21-24 June 1999; Larsen, A., Larose, G.L.L., Livesey, F.M., Eds.; Volume 1, pp. 179-184.

52. Astrup, P.; Larsen, S.E. WAsP Engineering Flow Model for Wind over Land and Sea; Risø-R-1107(EN); Risø National Laboratory for Sustainable Energy, Technical University of Denmark: Roskilde, Denmark, 1999.

(C) 2016 by the authors; licensee MDPI, Basel, Switzerland. This article is an open access article distributed under the terms and conditions of the Creative Commons Attribution (CC-BY) license (http://creativecommons.org/licenses/by/4.0/). 